\title{
Estimasi Gaya Tarik pada Kabel Jembatan Cable Stayed dengan Pengujian Dinamik
}

\author{
Hinawan Teguh Santoso \\ Prodi Konstruksi Jalan dan Jembatan, Politeknik Pekerjaan Umum \\ E-mail:hteguhsantoso@gmail.com
}

\begin{abstract}
ABSTRAK
Kabel merupakan salah satu elemen utama pada jembatan cable stayed yang fungsinya memikul dan meneruskan beban pada balok dan lantai jembatan ke struktur pilon. Elemen kabel perlu selalu dilakukan monitoring dan pemeliharaan selama umur jembatan, sehingga gaya tarik kabel yang bekerja tidak melampaui kapasitasnya. Salah satu metode dapat dilakukan dengan uji dinamik, di mana nilai parameter dinamik (frekuensi dan mode getar) berkorelasi dengan gaya tarik kabel. Selain parameter dinamik, gaya tarik kabel juga dipengaruhi oleh parameter fisiknya, yaitu parameter tak-berdimensi $\lambda^{2}$ akibat efek kelengkungan ( sag effect) dan parameter tak-berdimensi $\xi$ akibat efek kekakuan lentur (bending stiffness effect). Berbagai rumusan pendekatan telah dikembangkan oleh para ahli, di antaranya: taut string, beam string, wei-xin, dan zui et.al. theory. Studi ini akan membahas perbandingan rumusan tersebut dengan mengambil studi kasus Jembatan Pedamaran 1, Riau. Hasil studi menunjukkan bahwa parameter tak berdimensi $\lambda^{2}$ dan $\xi$ "cukup berpengaruh" dan perlu ditinjau dalam perhitungan, di mana kombinasi dari kedua parameter tersebut memberikan pengaruh sebesar $1.77 \%-6.00 \%$ terhadap estimasi gaya tarik kabel. Penggunaan rumusan empiris taut string theory dan beam string theory memberikan estimasi gaya tarik kabel dengan tingkat kesalahan di bawah $7,0 \%$, sedangkan rumusan empiris wei-xin dan zui et.al. memberikan hasil dengan akurasi paling baik dengan kesalahan di bawah $3,0 \%$.
\end{abstract}

Kata Kunci: cable stayed, taut string theory, beam string theory, gaya tarik kabel, pengujian dinamik

\section{ABSTRACT}

Cable is one of the main elements in cable stayed bridges whose function is to support and transfer the load on the beam and slab of the bridge to the pylon structure. Cable elements must always be monitored and maintained during the life of the bridge, so that the tension force of the working cable does not exceed its capacity. One method can be done with a dynamic test, where the value of dynamic parameters (frequency and vibration mode) correlates with the cable tension. In addition to dynamic parameters, the tensile strength of the cable is also influenced by its physical parameters, namely non-dimensional parameters $\lambda 2$ due to the sag effect and non-dimensional parameters $\xi$ due to the bending stiffness effect. Various approaches have been developed by experts, including taut string, beam string, wei-xin, dan zui et.al. theory. This study will discuss the comparison of these formulations by taking a case study of Pedamaran 1 Bridge, Riau. The results of the study showed that the non-dimensional parameters $\lambda 2$ and $\xi$ were "quite influential" and needed to be reviewed in calculations, where the combination of the two parameters had an effect of 1,77\% - 6,00\% on the estimated tension force of the cable. The use of empirical formulation of taut string theory and beam string theory provides estimates of cable tension force with errors below 7,0\%, while the empirical formulations of wei-xin and zui et.al. results with the best accuracy with errors below 3,0\%.

Keywords: cable stayed, taut string theory, beam string theory, cable tension force, dynamic test

\section{PENDAHULUAN}

Keberadaan konstruksi jembatan pada suatu ruas jalan memegang peranan yang cukup penting dalam hal menjaga konektivitas jaringan jalan. Perkembangan teknologi jembatan dan tuntutan kebutuhan jembatan yang dapat menghubungkan satu daerah ke daerah lain melewati sungai atau selat mendorong perkembangan konstruksi jembatan bentang panjang di Indonesia, salah satunya jembatan cable stayed. Binamarga [1] menjelaskan definisi dari jembatan cable stayed adalah struktur yang mempunyai sederetan kabel lurus yang dibentangkan miring, berfungsi memikul elemen horizontal kaku berupa balok, rangka dan boks yang dihubungkan ke menara (pilon) sebagai penahan utama. Dengan demikian, elemen utama dalam jembatan cable stayed adalah kabel dan pilon.

Kabel sebagai salah satu elemen utama dari jembatan cable stayed perlu untuk dilakukan monitoring dan pemeliharaan selama umur layan jembatan. Salah satu parameter utama yang diperhatikan yaitu besarnya gaya tarik kabel akibat menahan beban yang ada tidak melampaui dari kapasitas kabel yang ada. Salah satu metode pemeriksaan gaya yang bekerja pada kabel adalah dengan menggunakan uji dinamik (vibration test). Output dari pengujian ini berupa parameter dinamik, yaitu frekuensi getar yang selanjutnya dapat digunakan untuk menghitung estimasi besarnya gaya pada kabel. 
Kajian terkait metode perhitungan estimasi gaya pada kabel menggunakan uji dinamis pernah dilakukan oleh Byeong et.al. [3] pada Jembatan cable stayed Seohae, Korea. Hasil studi menunjukkan bahwa dari berbagai macam metode dan teori pendekatan yang digunakan memberikan nilai akurasi secara konsisten di bawah 3,00\% terhadap gaya aktual pada kabel. Kajian lain terkait validasi gaya kabel pada jembatan cable stayed juga dilakukan oleh Hidayat et. al. [6] pada Jembatan Merah Putih, Ambon dengan perbedaan hasil pengujian dan perhitungan estimasi gaya kabel sebesar 0,28\% - 9,23\% terhadap gaya kontrol kabel. Debora et.al. [9] menyatakan bahwa metode estimasi gaya tarik kabel berdasar nilai frekuensi dapat dilakukan dengan berbagai metode atau teori pendekatan dengan akurasi kesalahan di bawah 10,0\%. Metode paling sederhana dan mudah dilakukan yaitu dengan string theory meskipun mempunyai tingkat kesalahan paling besar, sedangkan metode yang paling banyak digunakan saat ini karena keakuratan hasilnya, yaitu wei-xin theory.

\section{STUDI PUSTAKA}

Metode estimasi besarnya gaya pada kabel berdasarkan uji dinamik ditentukan oleh parameter dinamik dan parameter fisik dari kabel. Parameter dinamik yang dimaksud adalah mode getar dan frekuensi dari kabel. Adapun parameter fisik kabel dipengaruhi oleh pengaruh kelengkungan kabel (sag effect) dan pengaruh kekakuan lentur kabel (bending stiffness effect). Pendekatan dengan formula empiris telah dikembangkan oleh beberapa ahli untuk memperkirakan besarnya gaya kabel berdasarkan uji dinamik dan dapat dikelompokkan ke dalam 4 teori, yaitu:

\subsection{Flat Taut String Theory}

Teori paling sederhana ini mengabaikan efek kelengkungan dan efek kekakuan lentur dari kabel.

$$
T=4 m L^{2}\left(\frac{f_{n}}{n}\right)^{2}
$$

di mana $T$ (gaya tarik kabel), $m$ (berat kabel), $L$ (panjang kabel), $f_{\mathrm{n}}$ (frekuensi pada mode $n$ ), dan $n$ (mode getar). Teori ini dengan mudah digunakan untuk menghitung gaya kabel berdasar nilai frekuensinya. Rumusan sederhana ini sesuai untuk kabel tunggal pendek dan mempunyai keterbatasan untuk kabel Panjang, di mana efek kelengkungan dan kekakuan lenturnya cukup tinggi. Namun demikian, rumusan ini dapat digunakan untuk membantu perkiraan awal gaya tarik kabel.

\subsection{Beam String Theory}

Dalam teori ini, rumusan pendekatan yang digunakan sudah memperhitungkan efek kekakuan lentur kabel yang direpresentasikan oleh nilai kekakuan material, yaitu $E I[10]$.

$$
\left(\frac{f_{n}}{n}\right)^{2}=\left(\frac{1}{4 m L^{2}}\right) T+\left(\frac{n^{2} \pi^{2}}{4 m L^{4}}\right) E I
$$

di mana $T$ (gaya tarik kabel), $m$ (berat kabel), $L$ (panjang kabel), $E$ (modulus elastisitas kabel), dan $I$ (inersia kabel). Pada rumusan ini, gaya kabel dan kekakuan lentur kabel belum diketahui, selanjutnya prosedur regresi linear digunakan untuk mengukur frekuensi dan mode getarnya. Rumusan ini lebih cocok digunakan pada kabel pendek dan kaku, dan kurang sesuai untuk kabel dengan efek kelengkungan yang tinggi. Terlepas dari keterbatasan itu, pendekatan ini sering digunakan dalam lapangan karena kesederhanaan dan kecepatannya.

\subsection{Wei-Xin Theory}

Referensi [11] memberikan suatu pendekatan formula di mana penggunaannya bergantung pada besaran parameter takberdimensi dari kabel, yaitu: $\lambda^{2}$ yang merepresentasikan pengaruh dari efek lengkungan kabel dan $\xi$ yang merepresentasikan pengaruh dari efek kekakuan lentur kabel.

2.3.1 Teori Wei-Xin (1) untuk perkiraan gaya tarik kabel dengan mempertimbangkan efek kelengkungan kabel:

$$
\begin{aligned}
& T=4 m\left(f_{1} L\right)^{2} ;\left(\lambda^{2} \leq 0,17\right) \\
& T=4 m\left(f_{1} L\right)^{2} ;\left(0,17<\lambda^{2}<4 \pi^{2}\right) \\
& T=m l^{2} f^{2} \quad ;\left(4 \pi^{2} \leq \lambda^{2}\right)
\end{aligned}
$$

2.3.2 Teori Wei-Xin (2) untuk perkiraan gaya tarik kabel dengan mempertimbangkan efek kekakuan lentur kabel:

$$
\begin{gathered}
T=3,432 m l^{2} f^{2}-45,191 \frac{E I}{l^{2}} ;(0,17 \leq \xi \leq 18) \\
T=m\left(2 l f-\frac{2,363}{l} \sqrt{E I / m}\right)^{2} ;(18<\xi \leq 210) \\
T=4 m l^{2} f^{2} \quad ;(210<\xi)
\end{gathered}
$$




\subsection{Combination Sag \& Bending Stiffness Theory}

Teori ini menggabungkan kombinasi pengaruh efek kelengkungan kabel dan efek kekakuan lentur dalam memperkirakan besarnya gaya tarik kabel. Zui et.al. [5] memberikan kriteria yang digunakan dalam formulanya, yaitu:

2.4.1 Kabel dengan pengaruh kelengkungan kecil $(\Gamma \geq 3)$,

$$
\begin{aligned}
& T=4 m\left(f_{1} L\right)^{2}\left[1-2,2 \frac{C}{f_{1}}-0,55\left(\frac{C}{f_{1}}\right)^{2}\right] ;\left(17 \leq \xi_{1}\right) \\
& T=4 m\left(f_{1} L\right)^{2}\left[0,865-11,6\left(\frac{C}{f_{1}}\right)^{2}\right] ;\left(6 \leq \xi_{1} \leq 17\right) \\
& T=4 m\left(f_{1} L\right)^{2}\left[0,828-10,5\left(\frac{C}{f_{1}}\right)^{2}\right] ;\left(0 \leq \xi_{1} \leq 6\right)
\end{aligned}
$$

2.4.2 Kabel dengan pengaruh kelengkungan besar $(\Gamma>3)$,

$$
\begin{aligned}
& T=m\left(f_{2} L\right)^{2}\left[1-4,40 \frac{C}{f_{2}}-1,10\left(\frac{C}{f_{2}}\right)^{2}\right] ;\left(60 \leq \xi_{1}\right) \\
& T=m\left(f_{2} L\right)^{2}\left[1,03-6,33 \frac{C}{f_{2}}-1,58\left(\frac{C}{f_{2}}\right)^{2}\right] ;\left(17 \leq \xi_{1} \leq 60\right) \\
& T=m\left(f_{2} L\right)^{2}\left[0,882-85,0\left(\frac{C}{f_{1}}\right)^{2}\right] ;\left(0 \leq \xi_{1} \leq 17\right)
\end{aligned}
$$

2.4.3 Kabel dengan mode getar yang lebih tinggi:

$$
\begin{gathered}
T=\frac{4 m}{n^{2}}\left(f_{1} L\right)^{2}\left[1-2,20 \frac{n C}{f_{n}}\right] ;\left(200 \leq \xi_{1}\right),(2 \leq n) \\
\operatorname{dimana,} C=\sqrt{(E I) /\left(m L^{4}\right)} ; \xi_{1}=\sqrt{T / E I} \cdot L ; \Gamma=\sqrt{(w L) /\left(128 E A m \delta^{3} \cos ^{5} \theta\right)}\left[\frac{0,31 \xi_{1}+0,5}{0,31 \xi_{1}-0,5}\right] \\
\delta=\text { rasio kelengkungan terhadap panjang }
\end{gathered}
$$

\section{METODE PENELITIAN}

\subsection{Objek Studi}

Penelitian ini akan mengambil studi kasus pada Jembatan Pedamaran I yang terletak di Kabupaten Rokan Hilir, Provinsi Riau. Jembatan ini mempunyai total panjang 1020,80 meter yang terdiri dari: 5 bentang pada jembatan utama, 9 bentang pada jembatan pendekat, dan beberapa rangkaian slab on pile. Konstruksi jembatan utama berupa cable stayed dengan bentang 111 meter, jembatan pendekat berupa concrete box girder dengan bentang 65 meter, serta konstruksi slab on pile sepanjang 216 meter.

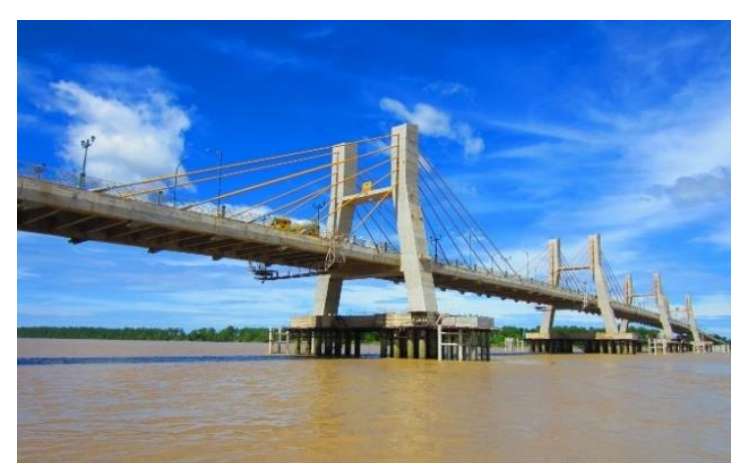

Gambar 1. Dokumentasi Jembatan Pedamaran I [Dok. Pribadi]

Pengujian dinamik pada elemen kabel dilaksanakan pada pilon P3 kiri atau sisi arah pulau, yaitu pada:

a) Kabel S1 - Sisi Bagan (Left Section),

b) Kabel S5 - Sisi Bagan (Left Section),

c) Kabel S1 - Sisi Tanjung (Right Section),

d) Kabel S5 - Sisi Tanjung (Right Section). 

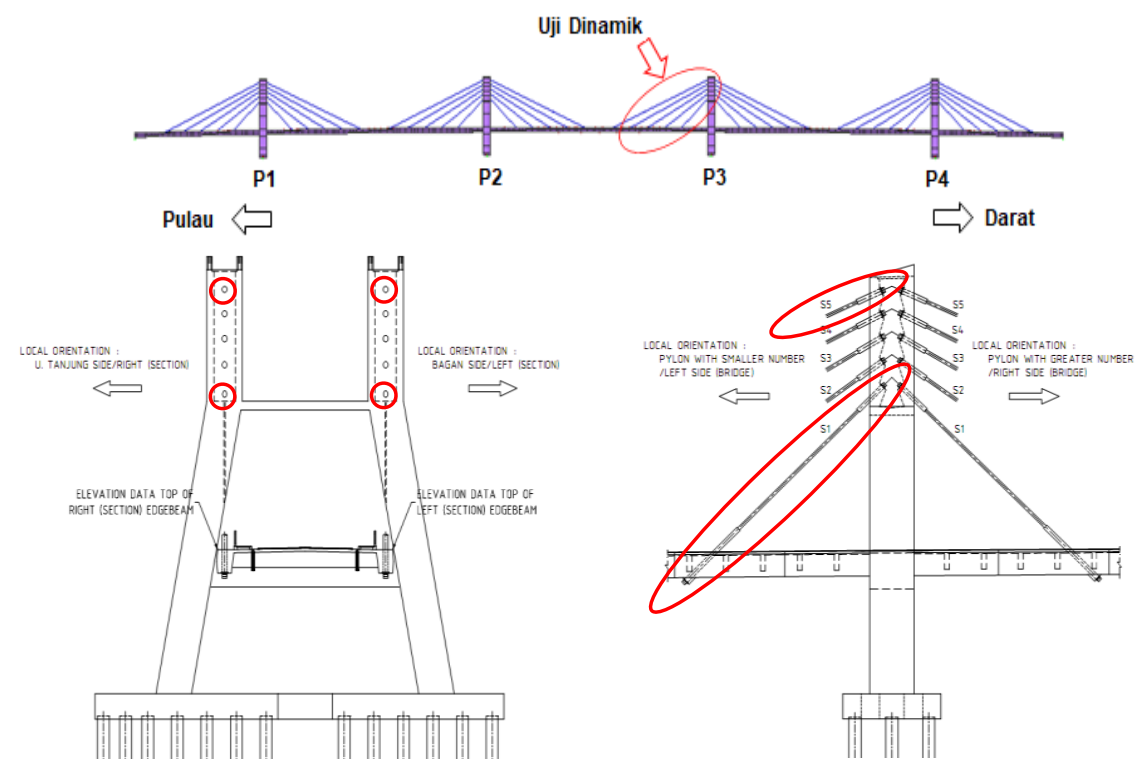

Gambar 2. Lokasi uji dinamik pada kabel S1 dan S5 di pilon P3 sisi pulau [8]

\subsection{Teknik Pengumpulan Data}

Pengujian dinamik pada elemen kabel dilakukan dengan menggunakan eksitasi beban luar, di mana sebuah hammer (berat $\pm 5 \mathrm{~kg}$ ) dipukulkan pada tendon kabel sehingga terjadi bangkitan getaran. Getaran tersebut akan diterima dan direkam oleh sensor accelerometer, untuk selanjutnya data disimpan dan ditampilkan secara numeris ataupun grafis menggunakan komputer.

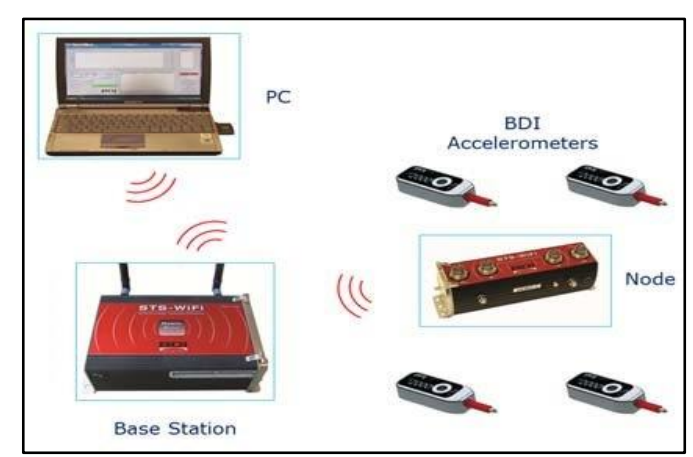

Gambar 3. Sensor accelerometer dan perangkat pengujian dinamik Bridge Diagnostic Inc. [4]

Data getaran hasil pembacaan sensor masih dalam domain waktu (time domain) dan selanjutnya diubah ke dalam domain frekuensi (frequency domain) dengan menggunakan metode FFT (Fast Fourier Transform) untuk mendapatkan nilai frekuensi getar dari kabel. Nilai frekuensi yang didapat digunakan untuk memperkirakan besarnya gaya tarik (tension) kabel menggunakan rumus empiris dan membandingkannya dengan gaya tarik (tension) kabel pada saat final lift-off jembatan yang dilakukan oleh kontraktor. Dokumentasi pelaksanaan uji dinamik pada elemen kabel jembatan disajikan pada Gambar 4.
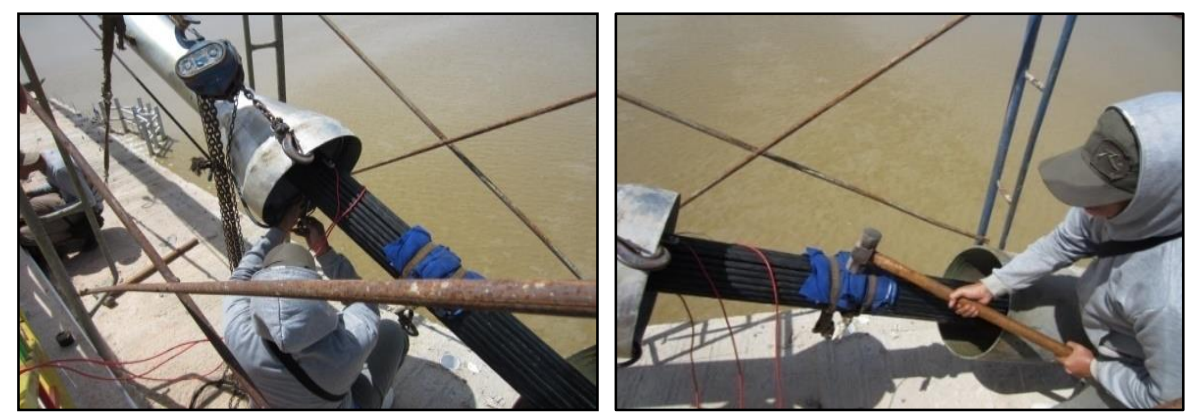

Gambar 4. Pemasangan sensor accelerometer dan eksitasi getaran dengan hammer

[Dok. Pribadi] 
Vol. 22, No. 1, Maret 2020

\section{DISKUSI}

\subsection{Data Properties Kabel}

Properties dari elemen kabel yang digunakan dalam studi disajikan pada Tabel 1.

Tabel 1. Data properties elemen kabel [8]

\begin{tabular}{|c|c|c|}
\hline $\begin{array}{l}\text { DS 6-37 } \\
\text { Kabel S1 }\end{array}$ & \multicolumn{2}{|c|}{$\begin{array}{c}\text { DS 6-55 } \\
\text { Kabel S5 }\end{array}$} \\
\hline Deskripsi & Kabel S1 & Kabel S5 \\
\hline Panjang (m) & 22.09 & 56.85 \\
\hline Jumlah strand (buah) & 37 & 55 \\
\hline Berat $(\mathrm{kg} / \mathrm{m})$ & 40,77 & 60,61 \\
\hline Luas Area $\left(\mathrm{m}^{2}\right)$ & $6,71 \times 10^{-3}$ & $9,98 \times 10^{-3}$ \\
\hline Mod. Elastisitas $\left(\mathrm{N} / \mathrm{m}^{2}\right)$ & $186 \times 10^{9}$ & $186 \times 10^{9}$ \\
\hline Momen Inersia $\left(\mathrm{m}^{4}\right)$ & $7,69 \times 10^{-6}$ & $13,67 \times 10^{-6}$ \\
\hline
\end{tabular}

\subsection{Data Final Lift-Off Cable Stay}

Berikut ini disajikan data final lift-off kabel Jembatan Padamaran I pada saat dilakukan final setting di tahap akhir pengecoran balok dan lantai jembatan.

Tabel 2. Data final lift-off kabel Pylon 3 [7]

\begin{tabular}{clc}
\hline No & \multicolumn{1}{c}{ Lokasi } & Gaya tarik/tension kabel (ton) \\
\hline 1 & Kabel S1 - Sisi Bagan & 235,33 \\
2 & Kabel S5 - Sisi Bagan & 346,65 \\
3 & Kabel S1 - Sisi Tanjung & 231,19 \\
4 & Kabel S5 - Sisi Tanjung & 349,06 \\
\hline
\end{tabular}

\subsection{Data Pengukuran Accelerometer dan Frekuensi}

Hasil rekaman getaran pada uji dinamik selanjutnya dilakukan analisis respons getaran dengan teknik FFT (Fast Fourier Transform) untuk mendapatkan frekuensi getar. Hasil analisis respons getaran dan FFT dapat dilihat pada Gambar 5 dan 6 , serta Tabel 3 dan 4.

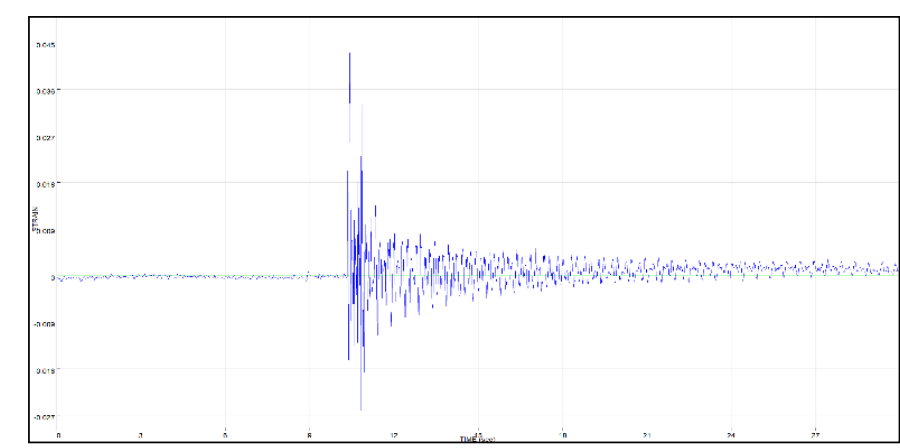

Gambar 5. Grafik respons getaran dalam domain waktu [2] 


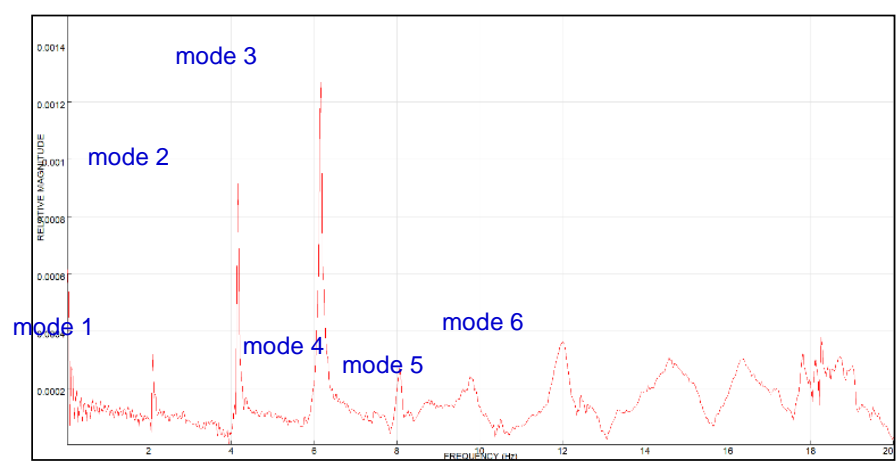

Gambar 6. Grafik respons dalam domain frekuensi [2]

Tabel 3. Frekuensi Hasil Uji Dinamik pada Kabel S1

\begin{tabular}{ccc}
\hline \multirow{2}{*}{ Mode ke- } & \multicolumn{2}{c}{ Frekuensi (Hz) } \\
\cline { 2 - 3 } & S1-Sisi Bagan & S1-Sisi Tanjung \\
\hline 1 & 5,64 & 5,57 \\
2 & 11,14 & 10,81 \\
3 & 16,91 & 16,81 \\
\hline
\end{tabular}

Tabel 4. Frekuensi Hasil Uji Dinamik pada Kabel S5

\begin{tabular}{ccc}
\hline \multirow{2}{*}{ Mode ke- } & \multicolumn{2}{c}{ Frekuensi (Hz) } \\
\cline { 2 - 3 } & S5-Sisi Bagan & S5-Sisi Tanjung \\
\hline 1 & 2,13 & 2,20 \\
2 & 4,20 & 4,34 \\
3 & 6,20 & 6,44 \\
4 & 8,44 & 8,77 \\
5 & 10,51 & 10,91 \\
6 & 12,51 & 12,67 \\
\hline
\end{tabular}

\subsection{Pengaruh Parameter Tak-Berdimensi $\lambda^{2}$ dan $\xi$}

Untuk mengetahui efek lengkungan kabel (sag effect) dan efek kekakuan lentur (bending stiffness effect) dari kabel, maka dapat digunakan rumus pendekatan seperti pada [11] dengan menghitung parameter tak-berdimensi $\lambda^{2} \mathrm{dan} \xi$.

Parameter tak-berdimensi $\lambda^{2}$ merepresentasikan pengaruh dari efek lengkungan kabel dimana terbagi dalam 3 kondisi, yaitu:

(a) $\lambda^{2} \leq 0,17 \rightarrow$ tidak ada pengaruh,

(b) $0,17 \leq \lambda^{2} \leq 4 \pi^{2} \rightarrow$ cukup berpengaruh,

(c) $\lambda^{2}>4 \pi^{2} \rightarrow$ sangat berpengaruh,

Sedangkan parameter tak-berdimensi $\xi$ merepresentasikan pengaruh dari efek kekakuan lentur dimana juga terbagi dalam 3 kondisi, yaitu:

(a) $0 \leq \xi \leq 18 \rightarrow$ tidak ada pengaruh,

(b) $18 \leq \xi \leq 210 \rightarrow$ cukup berpengaruh,

(c) $\xi>210 \rightarrow$ sangat berpengaruh,

Rumusan dari parameter tak-berdimensi $\lambda^{2}$ :

$$
\lambda^{2}=\left(\frac{m g l}{H}\right)^{2} \frac{E A L}{H L_{e}} ; L_{e}=1\left\{1+\frac{1}{8}\left(\frac{m g l}{H}\right)^{2}\right\}
$$

Rumusan dari parameter tak-berdimensi $\xi$ :

$$
\xi=\sqrt{\frac{T}{E I} l}
$$

dimana $m$ (berat kabel), $g$ (gravitasi), $E$ (modulus elastisitas, $A$ (luas area), $l$ (panjang kabel), $H$ (gaya kabel), $L e$ (panjang efektif kabel), $I$ (momen inersia), dan $T$ (gaya tarik kabel). Nilai $H$ diambil dari gaya pada kabel pada saat dilakukan final lift-off, Hasil perhitungan parameter tak-berdimensi $\lambda^{2}$ dan $\xi$ disajikan pada Tabel 5. 
Tabel 5. Frekuensi Hasil Uji Dinamik pada Kabel S5

\begin{tabular}{clcc}
\hline \multirow{2}{*}{ No } & \multicolumn{1}{c}{ Kabel } & \multicolumn{2}{c}{ Parameter tak-berdimensi } \\
\cline { 3 - 4 } & & $\lambda^{2}$ & $\xi$ \\
\hline 1 & S1 - Sisi Bagan & 0,75 & 28,11 \\
2 & S1 - Sisi Tanjung & 0,80 & 27,86 \\
3 & S5 - Sisi Bagan & 5,13 & 65,85 \\
4 & S5 - Sisi Tanjung & 5,02 & 66,08 \\
\hline
\end{tabular}

Berdasarkan perhitungan pada tabel di atas dapat diketahui bahwa akibat efek lengkungan kabel (sag effect), kabel yang diuji pada Jembatan Pedamaran I termasuk dalam kategori "cukup berpengaruh" dalam perhitungan gaya kabel $\left(0,17 \leq \lambda^{2} \leq 4 \pi^{2}\right)$. Sedangkan untuk efek kekakuan lentur (bending stiffness effect) juga termasuk dalam kategori "cukup berpengaruh" dalam perhitungan gaya kabel $(18 \leq \xi \leq 210)$. Besarnya pengaruh dari efek lengkungan kabel dan kekakuan lentur akan dibahas pada sub-bab selanjutnya.

\subsection{Perhitungan dan Analisis Gaya Tarik Kabel}

Dengan mempergunakan persamaan empiris dari beberapa teori yang telah disajikan pada sub-bab sebelumnya, didapatkan besarnya estimasi gaya tarik (tension force) dari kabel uji dan kemudian dibandingkan dengan data final lift-off kabel seperti tersaji pada tabel dan gambar berikut ini.

a) Kabel S1-Sisi Bagan

Tabel 6. Estimasi gaya tarik pada kabel S1-sisi Bagan

\begin{tabular}{ccccccc}
\hline \multirow{2}{*}{ Mode } & $\begin{array}{c}\text { Frekuensi } \\
(\mathrm{Hz})\end{array}$ & \multicolumn{5}{c}{ Gaya Tarik (Tension Force) - ton } \\
\cline { 3 - 7 } & 5,64 & 252,85 & 252,56 & 252,84 & 240,03 & 240,69 \\
1 & 11,14 & 246,89 & 245,71 & 246,87 & 234,22 & 234,87 \\
2 & 16,91 & 252,85 & 250,20 & 252,84 & 240,03 & 240,69 \\
3 & & 250,86 & 249,49 & 250,85 & 238,09 & 238,75 \\
\hline Rata-Rata & & & & & & \\
\hline
\end{tabular}

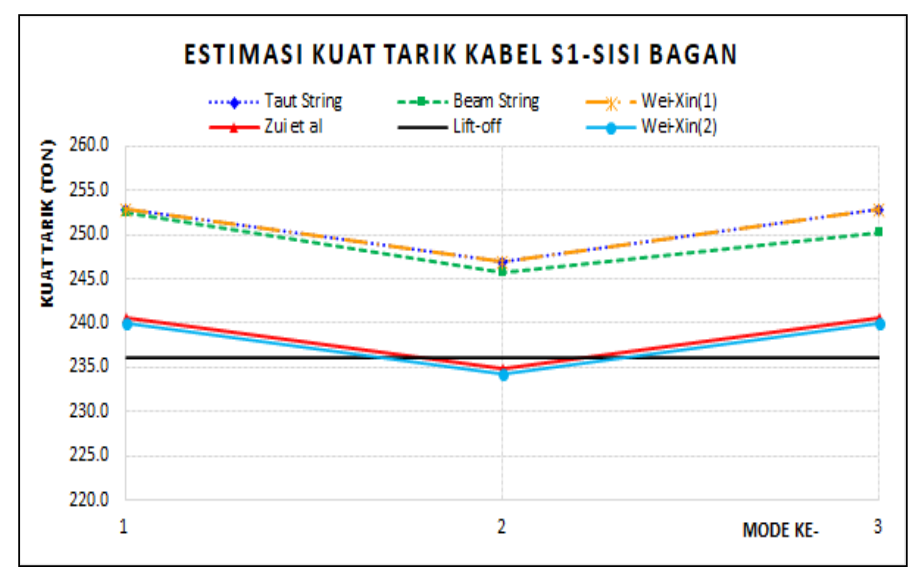

Gambar 7. Estimasi gaya tarik pada kabel S1-sisi Bagan

b) Kabel S1-Sisi Tanjung

Tabel 7. Estimasi gaya tarik pada kabel S1-sisi Tanjung

\begin{tabular}{ccccccc}
\hline \multirow{2}{*}{ Mode } & $\begin{array}{c}\text { Frekuensi } \\
(\mathrm{Hz})\end{array}$ & \multicolumn{5}{c}{ Gaya Tarik (Tension Force) - ton } \\
\cline { 3 - 7 } & 5,57 & 246,90 & 246,61 & 246,89 & 234,23 & 234,89 \\
1 & 10,81 & 232,34 & 231,16 & 232,32 & 220,05 & 220,68 \\
2 & 16,81 & 249,87 & 247,22 & 249,86 & 237,12 & 237,78 \\
\hline 3 & 250,86 & 249,49 & 243,02 & 230,47 & 238,75 \\
\hline \multicolumn{2}{l}{ Rata-Rata } & & & & & Beam String \\
\hline
\end{tabular}




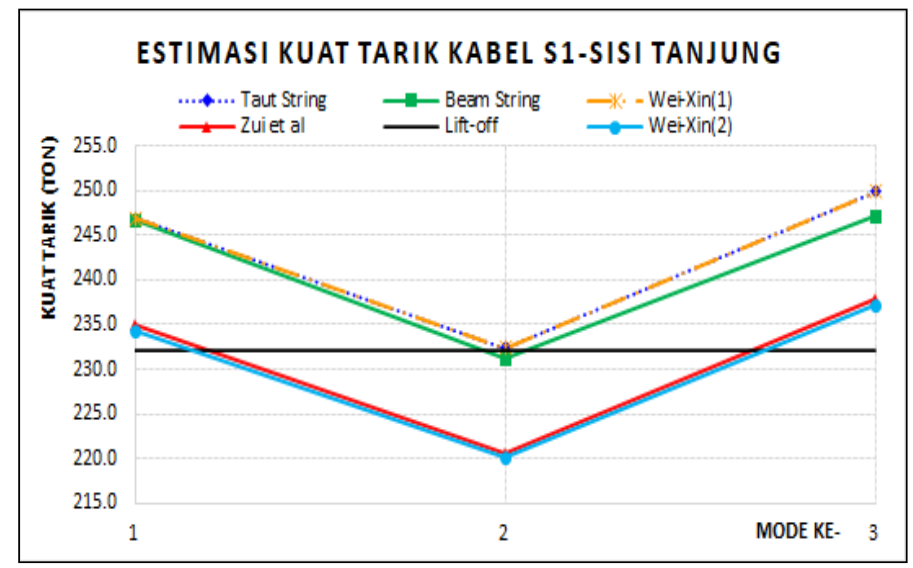

Gambar 8. Estimasi gaya tarik pada kabel S1-sisi Tanjung

c) Kabel S5-Sisi Bagan

Tabel 8. Estimasi gaya tarik pada kabel S5-sisi Bagan

\begin{tabular}{ccccccc}
\hline \multirow{2}{*}{ Mode } & $\begin{array}{c}\text { Frekuensi } \\
(\mathrm{Hz})\end{array}$ & \multicolumn{5}{c}{ Gaya Tarik (Tension Force) - ton } \\
\cline { 3 - 7 } & 2.13 & Taut String & Beam String & Wei-Xin(1) & Wei-Xin(2) & Zui et.al. \\
\hline 1 & 357.02 & 356.95 & 356.89 & 349,07 & 349.56 \\
2 & 4.20 & 345.94 & 345.62 & 345.80 & 338,11 & 338.59 \\
3 & 6.20 & 335.05 & 334.34 & 334.90 & 327,35 & 327.82 \\
4 & 8.44 & 348.69 & 347.43 & 348.55 & 340,83 & 341.32 \\
5 & 10,51 & 345,94 & 343,96 & 345,80 & 338,11 & 338,59 \\
6 & 12,51 & 340,47 & 337,63 & 340,33 & 332,71 & 333,18 \\
\hline Rata-Rata & & 345.52 & 344.32 & 345.38 & 337,70 & 338.18 \\
\hline
\end{tabular}

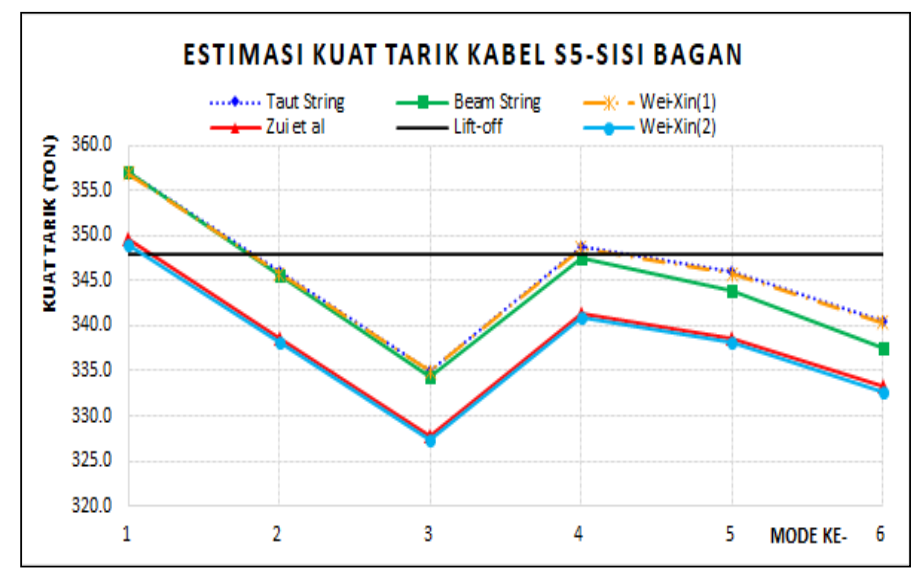

Gambar 9. Estimasi gaya tarik pada kabel S5-sisi Bagan

\section{d) Kabel S5-Sisi Tanjung}

Tabel 9. Estimasi gaya tarik pada kabel S5-sisi Tanjung

\begin{tabular}{ccccccc}
\hline \multirow{2}{*}{ Mode } & $\begin{array}{c}\text { Frekuensi } \\
(\mathrm{Hz})\end{array}$ & \multicolumn{5}{c}{ Gaya Tarik (Tension Force) - ton } \\
\cline { 3 - 7 } & 2,20 & 379,69 & 379,61 & 379,57 & 371,48 & 371.99 \\
1 & 4,34 & 368,25 & 367,93 & 368,13 & 360,17 & 360.67 \\
2 & 6,44 & 360,74 & 360,02 & 360,61 & 352,74 & 353.23 \\
3 & 8,77 & 376,80 & 375,54 & 376,68 & 368,63 & 369.13 \\
4 & 10,91 & 372,80 & 370,83 & 372,68 & 364,68 & 365.18 \\
5 & 12,67 & 349,62 & 346,77 & 349,48 & 341,74 & 342.23 \\
6 & & 367,98 & 366,78 & 367,86 & 359,91 & 360,40 \\
\hline Rata-Rata & & & & & & Beam String \\
\hline
\end{tabular}




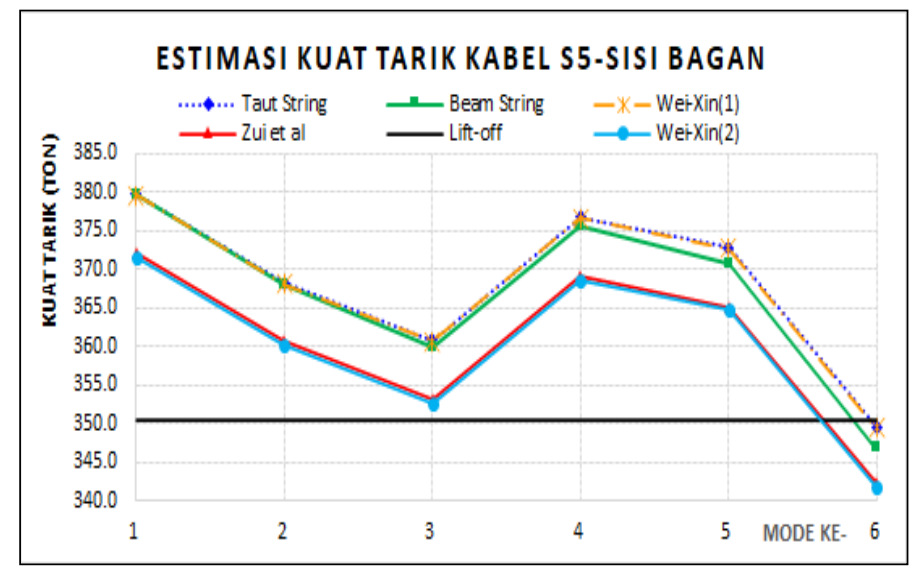

Gambar 10. Estimasi gaya tarik pada kabel S5-sisi Tanjung

Berdasarkan tabel dan grafik di atas, selanjutnya diperbandingkan hasil estimasi gaya tarik kabel dari masing-masing formula empiris terhadap data hasil final lift-off kabel.

Tabel 10. Perbandingan estimasi gaya tarik pada kabel S1-sisi Bagan dan S1-sisi Tanjung

\begin{tabular}{clcccc}
\hline No & \multicolumn{1}{c}{ Teori } & S1-Bagan & \% thd lift-off & S1-Tanjung & \% thd lift-off \\
\hline 1 & Taut String & 250,86 & 6,22 & 243,04 & 4,75 \\
2 & Beam String & 249,49 & 5,64 & 241,66 & 4,15 \\
3 & Wei-Xin (1) & 250,85 & 6,21 & 243,02 & 4,74 \\
4 & Wei-Xin (2) & 238,09 & 0,81 & 230,47 & 0,67 \\
5 & Zui et.al. & 238,75 & 1,09 & 231,11 & 0,39 \\
6 & Final lift-off & 236,18 & 0,00 & 232,02 & 0,00 \\
\hline
\end{tabular}

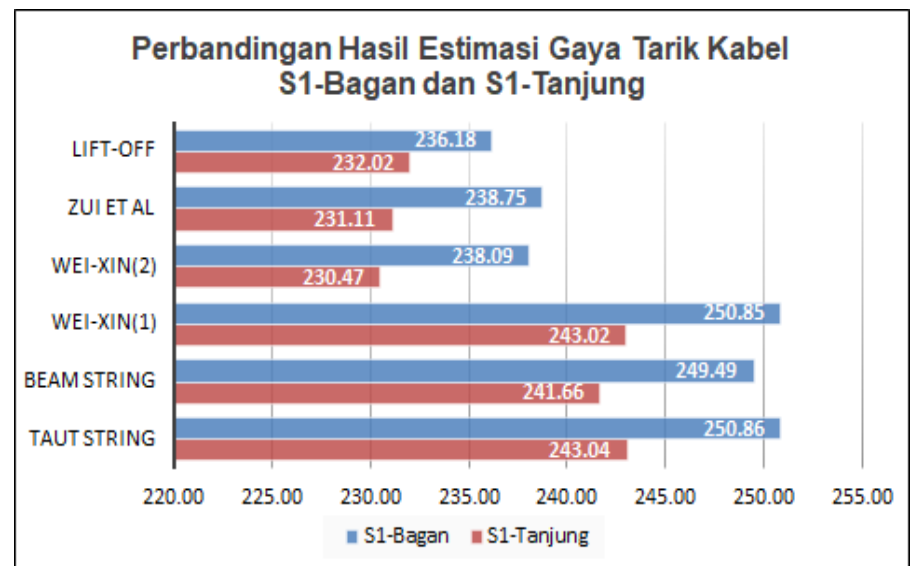

Gambar 11. Perbandingan estimasi gaya tarik pada kabel S1-sisi Bagan dan S1-sisi Tanjung

Tabel 11. Perbandingan estimasi gaya tarik pada kabel S5-sisi Bagan dan S5-sisi Tanjung

\begin{tabular}{clcccc}
\hline No & Teori & S5-Bagan & \% thd lift-off & S5-Tanjung & \% thd lift-off \\
\hline 1 & Taut String & 345,52 & 0,69 & 367,98 & 5,04 \\
2 & Beam String & 344,32 & 1,03 & 366,78 & 4,70 \\
3 & Wei-Xin (1) & 345,38 & 0,73 & 367,86 & 5,00 \\
4 & Wei-Xin (2) & 337,70 & 2,93 & 359,91 & 2,74 \\
5 & Zui et.al. & 338,18 & 2,80 & 360,40 & 2,88 \\
6 & Final lift-off & 347,90 & 0,00 & 350,32 & 0,00 \\
\hline
\end{tabular}




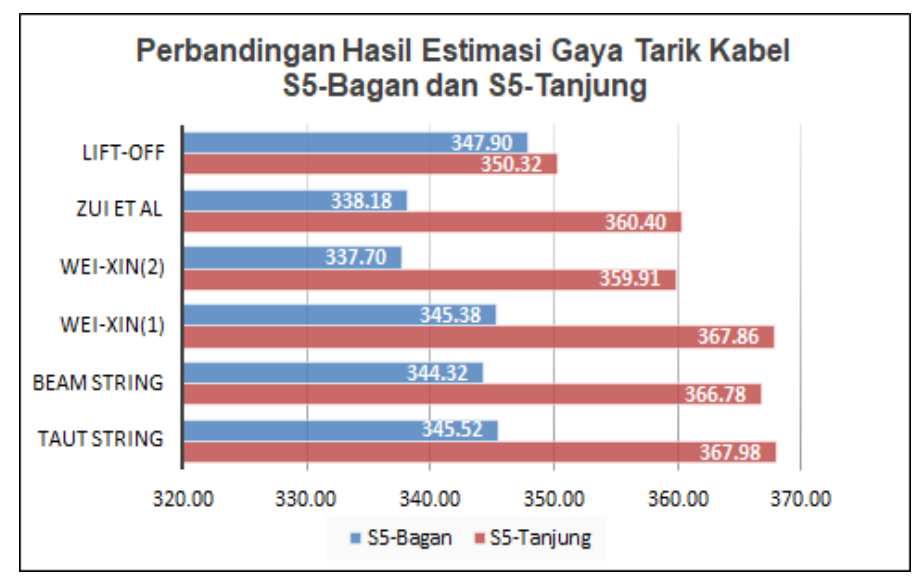

Gambar 12. Perbandingan estimasi gaya tarik pada kabel S5-sisi Bagan dan S5-sisi Tanjung

Dari Tabel 10 dan 11, serta Gambar 11 dan 12 dapat dilihat bahwa pengaruh efek lengkungan kabel (sag effect) pada kabel panjang (S5) memberikan pengaruh yang lebih besar jika dibandingkan pada kabel yang pendek (S1). Hal tersebut terlihat pada perbandingan antara teori Taut String dengan Wei-Xin (1), di mana kabel panjang (S5) memberikan pengaruh 0,04\% apabila dibandingkan dengan kabel pendek (S1) sebesar 0,01\%. Sebaliknya, efek kekakuan lentur (bending stiffness effect) pada kabel pendek (S1) memberikan pengaruh yang lebih besar jika dibandingkan pada kabel yang panjang (S5). Hal tersebut terlihat pada perbandingan teori Taut String dengan teori Wei-Xin (2), di mana kabel pendek (S1) memberikan pengaruh 4,08\% - 5,41\% bila dibandingkan dengan kabel panjang (S5) sebesar 2,25\% - 2,30\%.

Selanjutnya, pengaruh efek kekakuan lentur yang dihitung menggunakan teori Beam String dan Wei-Xin (2) memberikan pengaruh yang lebih besar apabila dibandingkan pengaruh efek lengkungan kabel yang dihitung dengan teori Wei-Xin (1). Hal tersebut terlihat pada perbandingan antara teori Taut String dengan Wei-Xin (1) turun sekitar 0,01\% - 0,04\%, sedangkan pada perbandingan antara teori Taut String dengan teori Beam String turun sebesar 0,34\% - 0,59\% dan apabila dibandingkan teori Wei-Xin (2) turun sebesar 2,25\% - 5,41\%. Dengan menggunakan teori Zui et.al., di mana metode ini sudah memperhitungkan kombinasi kedua efek tersebut, didapatkan penurunan gaya tarik sebesar 1,77\% - 4,55\% dari gaya tarik saat final lift-off. Dengan demikian, berdasar beberapa teori yang digunakan dapat disimpulkan bahwa kombinasi dari efek lengkungan kabel dan efek kekakuan lentur memberikan pengaruh terhadap estimasi gaya tarik kabel sebesar 1,77\% - 6,00\% dari gaya tarik saat final lift-off.

Ditinjau dari ketepatan hasil estimasi kuat tarik kabel, dapat dilihat bahwa teori Taut String memberikan akurasi hasil yang paling kecil, dengan nilai selisih 6,22\% (kecuali pada kabel S5-Bagan). Akurasi paling besar berturut-turut dapat diperoleh menggunakan teori Wei-Xin (2) dengan rentang nilai 0,67\% - 2,93\% dan teori Zui et.al. dengan rentang nilai 0,39\% - 2,88\%.

\section{KESIMPULAN}

Berdasarkan hasil analisis dan diskusi yang dilakukan dapat diperoleh beberapa kesimpulan, yaitu:

a) Parameter tak berdimensi $\lambda^{2}$ dan $\xi$ untuk seluruh kabel yang diuji masuk dalam kategori "cukup berpengaruh". Hal tersebut menunjukkan bahwa efek kelengkungan kabel (sag effect) dan efek kekakuan lentur (bending stiffness effect) perlu ditinjau dalam perhitungan estimasi gaya tarik kabel.

b) Pengaruh efek lengkungan kabel pada kabel panjang (S5) memberikan pengaruh yang lebih besar jika dibandingkan pada kabel yang pendek (S1). Sebaliknya, efek kekakuan lentur pada kabel pendek (S1) memberikan pengaruh yang lebih besar jika dibandingkan pada kabel yang panjang (S5).

c) Kombinasi dari efek lengkungan kabel dan efek kekakuan lentur memberikan pengaruh terhadap estimasi gaya tarik kabel sebesar $1,77 \%$ - 6,00\% dari gaya tarik saat final lift-off.

d) Besarnya gaya tarik (tension) kabel dapat dilakukan estimasi berdasarkan pengujian dinamik dan pendekatan formula empiris yang ada dengan hasil yang akurat. Teori Taut String dan Beam String memberikan estimasi gaya tarik kabel dengan kesalahan di bawah 7,0\%, sedangkan teori Wei-Xin dan Zui et.al. memberikan hasil akurasi paling baik dengan kesalahan di bawah $3,0 \%$.

\section{DAFTAR PUSTAKA}

[1] Binamarga, Manual Konstruksi dan Bangunan No.019/BM/2011 tentang Pemeliharaan Jembatan Cable Stayed, Jakarta, 2011. 
[2] Binamarga, Laporan Pelaksanaan Uji Beban Jembatan Pedamaran I, Kab. Rokan Hilir, Prov. Riau, Jakarta, 2013.

[3] Byeong Hwa Kim, Taehyo Park, Hyungyang Shin, dan Tae-Yang Yoon, “A Comparative Study of Tension Estimation Method For Cable Supported Bridges”, Steel Structures 7 (2007), pp.77-84, 2007.

[4] D.C. Nguyen, H.V. Tran, H.Q. Hung, T.V. Mot, "Development and Application of Structural Health Monitoring using LowCost MEMS and Arduino Nano Microcontroller Board”. 9-2018. 154-158, 2018.

[5] H. Zui, T. Shinke dan Y.H. Namita, "Practical Formulas for Estimation of Cable Tension by Vibration Method", Journal of Structural Engineering, ASCE, 122(6), pp. 651-656, 1996.

[6] I. Hidayat, M. Suangga, dan G. Siagian, "Validation Value of Cable Force Using the Accelerometer", IOP Conference Series: Earth and Environmental Science. 195. 012022.10.1088/17551315/195/1/012022, 2018.

[7] PT. VSL Indonesia, Data Final Lift-Off Jembatan Pedamaran I, Rokan Hilir, 2013.

[8] PT. Waskita Karya (Persero), Shop-Drawing Pembangunan Jembatan Pedamaran I, Rokan Hilir, 2013.

[9] S.N. Debora, R. Raja, S. Jannet, R. Reddy, J.J. Vasanth, dan U.A. Menon, “Assessment of Cable Tension Vibration Based Methodologies For Wireless Structural Health Monitoring”, International Journal of Mechanical and Production Engineering Research and Development, Vol.8, Issue 2, pp.575-582, 2018.

[10] T. Shimada, K. Kimoto, dan S. Narui, "Study On Estimating Tension of Tied Hanger Rope of Suspension Bridge by Vibration Method", Proc. JSCE, 404(I-11), pp.455-458, 1989.

[11] Wei-Xin Ren, Gang Chen, dan Wei-Hua Hu, "Empirical Formulas to Estimate Cable Tension by Cable Fundamental Frequency", Structural Engineering and Mechanics, Vol. 20, No. 3, pp.363-380, 2005. 